\title{
Hydroxytyrosol Selectively Affects Non-Enzymatic Glycation in Human Insulin and Protects by AGEs Cytotoxicity
}

\author{
Ivana Sirangelo ${ }^{1,2} \mathbb{D}$, Margherita Borriello ${ }^{1,2}$, Maria Liccardo ${ }^{1}$, Marika Scafuro ${ }^{1}$, Paola Russo ${ }^{1,2}$ and \\ Clara Iannuzzi $1, * \mathbb{D}$ \\ 1 Department of Precision Medicine, Università degli Studi della Campania "Luigi Vanvitelli", \\ Via L. De Crecchio 7, 80138 Naples, Italy; ivana.sirangelo@unicampania.it (I.S.); \\ margherita.borriello@unicampania.it (M.B.); maria.liccardo@unicampania.it (M.L.); \\ marika.scafuro@unicampania.it (M.S.); prusso@isa.cnr.it (P.R.) \\ 2 Institute of Food Sciences, National Research Council, ISA-CNR, Via Roma 64, 83100 Avellino, Italy \\ * Correspondence: clara.iannuzzi@unicampania.it
}

Citation: Sirangelo, I.; Borriello, M.; Liccardo, M.; Scafuro, M.; Russo, P.; Iannuzzi, C. Hydroxytyrosol Selectively Affects Non-Enzymatic Glycation in Human Insulin and Protects by AGEs Cytotoxicity. Antioxidants 2021, 10, 1127. https:// doi.org/10.3390/antiox10071127

Academic Editor: Domenico Nuzzo

Received: 15 June 2021

Accepted: 13 July 2021

Published: 15 July 2021

Publisher's Note: MDPI stays neutral with regard to jurisdictional claims in published maps and institutional affiliations.

Copyright: (C) 2021 by the authors Licensee MDPI, Basel, Switzerland. This article is an open access article distributed under the terms and conditions of the Creative Commons Attribution (CC BY) license (https:// creativecommons.org/licenses/by/ $4.0 /)$.

\begin{abstract}
Hydroxytyrosol (HT), the major phenolic compound in olive oil, is attracting increasing interest for its beneficial properties including a notable antioxidant and anti-inflammatory power. In this study, using a combination of biophysical and cell biology techniques, we have tested the role of HT in the formation of advanced glycation end-products (AGEs). AGEs have a key role in clinical sciences as they have been associated to diabetes, neurodegenerative and cardiovascular diseases. In addition, as the incidence of Alzheimer's disease (AD) is strongly increased in diabetic patients, AGE formation is supposed to be involved in the development of the pathological hallmarks of AD. Our data show that HT selectively inhibits protein glycation reaction in human insulin, and it is able to counteract the AGE-induced cytotoxicity in human neurotypical cells by acting on SIRT1 level and oxidative stress, as well as on inflammatory response. This study identifies new beneficial properties for HT and suggests it might be a promising molecule in protecting against the AGE-induced toxicity, a key mechanism underlying the development and progression of neurodegenerative disorders.
\end{abstract}

Keywords: protein glycation; hydroxytyrosol; antioxidant; AGE toxicity

\section{Introduction}

Neurodegenerative diseases represent different conditions which primarily affect the neurons in the human brain. Currently, neurodegenerative diseases are incurable, and the treatments only affect the symptoms or delay the progression of the disease. Significant research has been devoted to the identification of mechanisms and risk factors involved in the multifactorial etiopathogenesis of these diseases. Recent studies have shown that the accumulation of advanced glycation end-products (AGEs) is a major factor in the incidence and development of several chronic disease, such as diabetes mellitus and its microvascular complications (atherosclerosis, cataracts, and nephropathies), as well as neuropathies [1-5]. In particular, high serum levels of AGEs have been associated to a faster rate of cognitive decline and increasing evidence suggest that AGEs could be implicated in the progression of Alzheimer's, Parkinson's disease, and cerebrovascular dementia [4-7]. In this respect, the incidence of Alzheimer's disease (AD) is strongly increased in diabetic patients, thus suggesting that AGE formation could be actively involved in the development of the pathological hallmarks of AD [8-13]. AGEs are a chemically heterogeneous group of compounds which result from the non-enzymatic glycation reaction between reducing sugars (and their derivatives) and amino-containing biomolecules such as proteins $[14,15]$. Although the physiological AGE formation is quite slow because of the relatively low reaction temperature, accumulation of AGEs is markedly accelerated by the high glucose levels and oxidative conditions in hyperglycemia and aging [16-19]. The formation and the accumulation of AGEs can affect protein function through several interrelated mechanisms 
including protein-protein cross-linking, changes in charge distribution, decreased protein half-life, compromised structural integrity, and altered protein conformation. AGE effect on protein structure depends on different factors including the reactivity of specific amino groups, reactive sugar concentration, and protein half-life [20,21]. In addition, protein glycation has been shown to directly affect the amyloid aggregation process and proteins in amyloid deposits are often found glycated suggesting a direct correlation between protein glycation and amyloidosis [21-26].

Besides affecting protein function and structure, AGE species stimulate cells via several receptors including advanced glycation end products (RAGE) inducing oxidative stress, inflammatory response, and gene expression [27-30]. RAGE signaling and downstream pathways have been implicated in a wide range of inflammatory-related pathologic conditions such as cardiovascular disease, arteriosclerosis, cancer progression, and arthritis [31-35]. The AGE-RAGE signaling has been also implicated in AD pathogenesis and other neurodegenerative diseases $[3,36,37]$. The AGE-RAGE interaction triggers a series of signal transduction cascades and leads to the activation of transcription factor NF- $\mathrm{kB}$ as well as release of pro-inflammatory molecules such as cytokines, chemokines, and adhesion molecules [38,39]. The activation of NF- $\mathrm{KB}$ can promote a positive loop that amplify the cellular response to external stress through the upregulation of RAGE expression [40,41]. Moreover, binding of AGEs to RAGE stimulates the generation of reactive oxygen species (ROS) by activation of NADPH oxidase [42-44].

Significant efforts have been made to identify compounds able to inhibit the glycation reaction or contrast AGE-induced toxicity with the aim of developing new potential therapeutic strategies $[45,46]$. In this respect, plant polyphenols have attracted considerable interest due to their multiple biological activities, including anti-oxidant, anti-inflammatory, anti-diabetic, anti-aggregation, and anti-cancer power [47-51]. Mainly, the anti-glycation activity of the phenolic compounds is attributed to the antioxidant activity through the free radical scavenging and dicarbonyl-trapping capacity [50,52].

Hydroxytyrosol (3,4-dihydroxyphenylethanol, HT) is the main phenolic compound in olive oil, and it has been widely studied for its beneficial health properties (Figure 1). The free radical scavenging activity and the increase of the endogenous defense systems by HT and its metabolites could be involved in the prevention of different pathologies caused by oxidative stress such as inflammation, cancer, diabetes, cardiovascular, and neurodegenerative diseases [53-57]. Recently, an antiglycation effect exerted by olive leaf extract has also been reported [58].<smiles>OCCc1ccc(O)c(O)c1</smiles>

Figure 1. Chemical structure of hydroxytyrosol (HT).

In this study, we have tested the effect of HT both on glycation reaction and AGEinduced toxicity using human insulin as protein model. Our results show that HT strongly restrains insulin glycation reaction, and it is able to counteract the AGE-induced toxicity by acting on SIRT1 level and oxidative stress, as well as on inflammatory response by inhibiting NF- $\mathrm{kB}$ and Erk $1 / 2$ activation.

\section{Materials and Methods}

\subsection{Materials}

Human insulin, hydroxytyrosol, $N$-acetyl-L-tyrosine-ethyl ester, methylglyoxal (MG), D-ribose, 3-(4,5-dimethylthiazol-2-yl)-2,5-diphenyl-tetrazolium bromide (MTT), protease 
inhibitor cocktail (Sigma-Aldrich Co., St. Louis, MO, USA). Anti-SIRT1 (E104) (ab32441) (Abcam, Cambridge, UK); Anti-SOD2 (D9V9C), Anti-GAPDH (D16H11) (\#5174), anti-p42 MAPK (ERK1) (\#9102), anti-phospho-p44/42 MAPK (ERK1/2) (Thr202/Tyr204) (\#9101) and anti-phospho-NF-кB p65 (Ser536) (\#3031) (Cell Signaling Technology, Boston, MA, USA); Anti- $\alpha$-tubulin (B-7) (sc-5286) (Santa Cruz Biotechnology, Santa Cruz, CA, USA). Secondary antibodies: goat anti-rabbit (GtxRb-003-DHRPX) and goat anti-mouse (GtxMu003-EHRPX.0.05) (Immunoreagents Inc., Raleigh, NC, USA). SH-SY5Y cell lines (CRL-2266, ATCC, VA, USA). All other chemicals were of analytical grade. MG was further purified by distillation under low pressure and its concentration was determined spectrophotometrically using $\varepsilon_{284}=12.3 \mathrm{M}^{-1} \mathrm{~cm}^{-1}[59]$.

\subsection{Insulin Preparation and Glycation}

Human insulin was dissolved in ultra-pure milliQ water to a final concentration of $4 \mathrm{mg} / \mathrm{mL}$ at $\mathrm{pH} 2.0$ and protein concentration was determined by absorbance $\left(\varepsilon_{275}=4560 \mathrm{M}^{-1} \mathrm{~cm}^{-1}\right)$. Finally, insulin was neutralized to $\mathrm{pH} 7.0$ and kept in phosphate buffer $50 \mathrm{mM}$, pH 7.0. HT was dissolved in ultra-pure milliQ water at $100 \mathrm{mM}$ concentration. Glycated insulin was prepared mixing human insulin at a final concentration of $1 \mathrm{mg} / \mathrm{mL}$ and $1 \mathrm{mM} \mathrm{MG}$ or $0.5 \mathrm{M}$ D-ribose in $50 \mathrm{mM} \mathrm{NaH}_{2} \mathrm{PO}_{4}$ buffer, $\mathrm{pH}$ 7.0, passed through a $0.22 \mu \mathrm{m}$ filter and incubated at $37^{\circ} \mathrm{C}$ in sterile conditions in the absence and in the presence of $0.5,1$, and $2 \mathrm{mM}$ HT. Human insulin in the absence and in the presence of HT without glycating agent was used as protein control. Aliquots of protein were collected in sterile conditions and immediately analyzed.

\subsection{Fluorescence Measurements}

Fluorescence measurements were performed on a Perkin Elmer Life Sciences LS 55 spectrofluorometer. To assess the intrinsic fluorescence of AGEs ( $\lambda$ ex $320 \mathrm{~nm} / \lambda \mathrm{em} 410 \mathrm{~nm})$, glycated insulin at a final concentration of $8 \mu \mathrm{M}$ was monitored at different incubation times with the glycating agent in the absence and in the presence of HT. The fluorescence intensity was corrected by subtracting the emission intensity of D-ribose/MG solutions at different incubation times. Tyrosine fluorescence emission ( $\lambda$ ex $275 \mathrm{~nm} / \lambda \mathrm{em} 305 \mathrm{~nm}$ ) was evaluated on $10 \mu \mathrm{M}$ glycated insulin after addition of HT at different insulin:HT molar ratio $(1: 0,1: 0.5,1: 1,1: 2)$.

\subsection{Cellular Cultures and Treatments}

SH-SY5Y human neuroblastoma cells were cultured in Eagle's minimum essential medium supplemented with $10 \%$ fetal bovine serum, $3.0 \mathrm{mM}$ glutamine, $50 \mathrm{U} / \mathrm{mL}$ penicillin and $50 \mathrm{mg} / \mathrm{mL}$ streptomycin in a $5.0 \% \mathrm{CO}_{2}$ humidified environment at $37^{\circ} \mathrm{C}$. Cells were exposed for $24 \mathrm{~h}$ to insulin glycated by D-ribose for seven days (final concentration $30 \mu \mathrm{M})$ in the absence and in the presence of HT 30 (1:1 molar ratio) and 60 (1:2 molar ratio) $\mu \mathrm{M}$. The protective effect of HT was monitored at 24 and $48 \mathrm{~h}$ by coincubation of cells with $30 \mu \mathrm{M}$ of fully ribosylated insulin and HT at different molar ratio (1:1, 1:2). For all experiments, untreated cells and cells incubated in the presence of only HT at the tested concentrations served as control.

\subsection{MTT Assay}

Cell viability was assessed as the inhibition of the ability of cells to reduce the metabolic dye 3-[4,5-dimethylthiazol-2-yl]-2,5-diphenyltetrazolium bromide (MTT) to a blue formazan product. After indicated times of incubation with protein samples, cells were rinsed with phosphate buffer solution (PBS). A stock solution of MTT (5 mg/mL in PBS) was diluted ten times in cell medium and incubated with cells for $3 \mathrm{~h}$ at $37^{\circ} \mathrm{C}$. After removing the medium, cells were treated with isopropylalcohol, $0.1 \mathrm{M} \mathrm{HCl}$ for $20 \mathrm{~min}$. Levels of reduced MTT were assayed by measuring the difference in absorbance between 570 and $690 \mathrm{~nm}$. Data are expressed as average percentage reduction of MTT with respect to the control \pm S.D. Data are an average from five independent experiments carried out in triplicate. 


\subsection{Detection of Intracellular ROS}

Intracellular ROS were detected by means of an oxidation-sensitive fluorescent probe $2^{\prime}, 7^{\prime}$-dichlorofluorescin diacetate (DCFH-DA). Cells were grown in 12-well plates, preincubated with DCFH-DA for $30 \mathrm{~min}$, and then incubated with protein samples for $48 \mathrm{~h}$. Control experiments were performed using untreated cells and cells were exposed to a $0.001 \mathrm{M} \mathrm{H}_{2} \mathrm{O}_{2}$. After incubation, cells were washed twice with PBS buffer and then lysed with Tris- $\mathrm{HCl} 0.5 \mathrm{M}, \mathrm{pH}$ 7.6, and 1\% SDS. The non-fluorescent DCFH-DA is converted, by oxidation, to the fluorescent molecule $2^{\prime}, 7^{\prime}$-dichlorofluorescein (DCF). DCF fluorescence intensity was quantified on a Perkin Elmer Life Sciences LS 55 spectrofluorometer using an excitation wavelength of $488 \mathrm{~nm}$ and an emission wavelength of $530 \mathrm{~nm}$. Data are expressed as average \pm S.D. from five independent experiments carried out in triplicate.

\subsection{Immunoblotting}

Cells were collected by centrifugation, resuspended in lysis buffer $(10 \mathrm{mM}$ Tris $\mathrm{pH}$ $8.0,150 \mathrm{mM} \mathrm{NaCl}, 10 \mathrm{mM} \mathrm{NaF}, 1 \mathrm{mM}$ dithiothreitol, $1 \% \mathrm{NP}-40$, along with the protease inhibitor cocktail and allowed to swell on ice for $20 \mathrm{~min}$. The supernatant was taken after centrifugation at $12,000 \times \mathrm{g}$ at $4{ }^{\circ} \mathrm{C}$ for $30 \mathrm{~min}$, and protein concentration was estimated using Bradford's reagent (BioRad, Hercules, CA, USA). Proteins $(25 \mu \mathrm{g})$ were separated by $10 \%$ SDS-PAGE under reducing conditions and blotted onto a polyvinylidene difluoride membrane in transfer buffer ( $25 \mathrm{mM}$ Tris, $192 \mathrm{mM}$ glycine, 20\% methanol, $0.1 \%$ SDS). The blots were then probed with indicated primary antibodies, followed by the corresponding horseradish peroxidase (HRP)-conjugated secondary antibodies. Immunoreactive bands were visualized using an enhanced chemiluminescence detection kit (EuroClone, Milan, Italy) with Chemi Doc XR (Biorad, Hercules, CA, USA). The relative intensity of protein bands was quantified using a Gel Doc XR System (Biorad, Hercules, CA, USA). Densitometry analysis was performed using ImageJ software, processing the digital image and converting the intensity of every protein band in an arithmetic value. Data analysis was performed comparing treated samples vs. control and normalized using the housekeeping gene.

\subsection{Statistical Analysis}

Statistical analyses were performed using Stata software (Version 13.0; StataCorp LP., College Station, TX, USA). Tukey's post hoc test was used if the treatment was significant on analysis of variance (ANOVA). All data are represented as the mean \pm SE. Statistical significance was set at $p<0.05$.

\section{Results}

\subsection{HT Effect on Insulin-AGE Formation and Cytotoxicity}

Insulin can be glycated by glucose, D-ribose, and other highly reactive carbonyls, such as methylglyoxal (MG), especially in diabetic conditions [60-66]. We have previously shown that both D-ribose and MG can react with human insulin producing fully glycated protein in few days $[65,67]$. To monitor the effect of HT in insulin glycation process, the reaction has been performed both in the presence and in the absence of HT and AGE formation estimated by fluorescence spectroscopy. Indeed, AGEs are characterized by a typical fluorescence emission at $410 \mathrm{~nm}$ upon excitation at $320 \mathrm{~nm}$ [68]. To this aim, insulin samples have been incubated at $37^{\circ} \mathrm{C}$ with $0.5 \mathrm{M}$ D-Ribose or $0.5 \mathrm{mM} \mathrm{MG}$ in the presence of different concentrations of HT $(0.5 ; 1 ; 2 \mathrm{mM})$, and AGE fluorescence was monitored in time (Figure 2). 

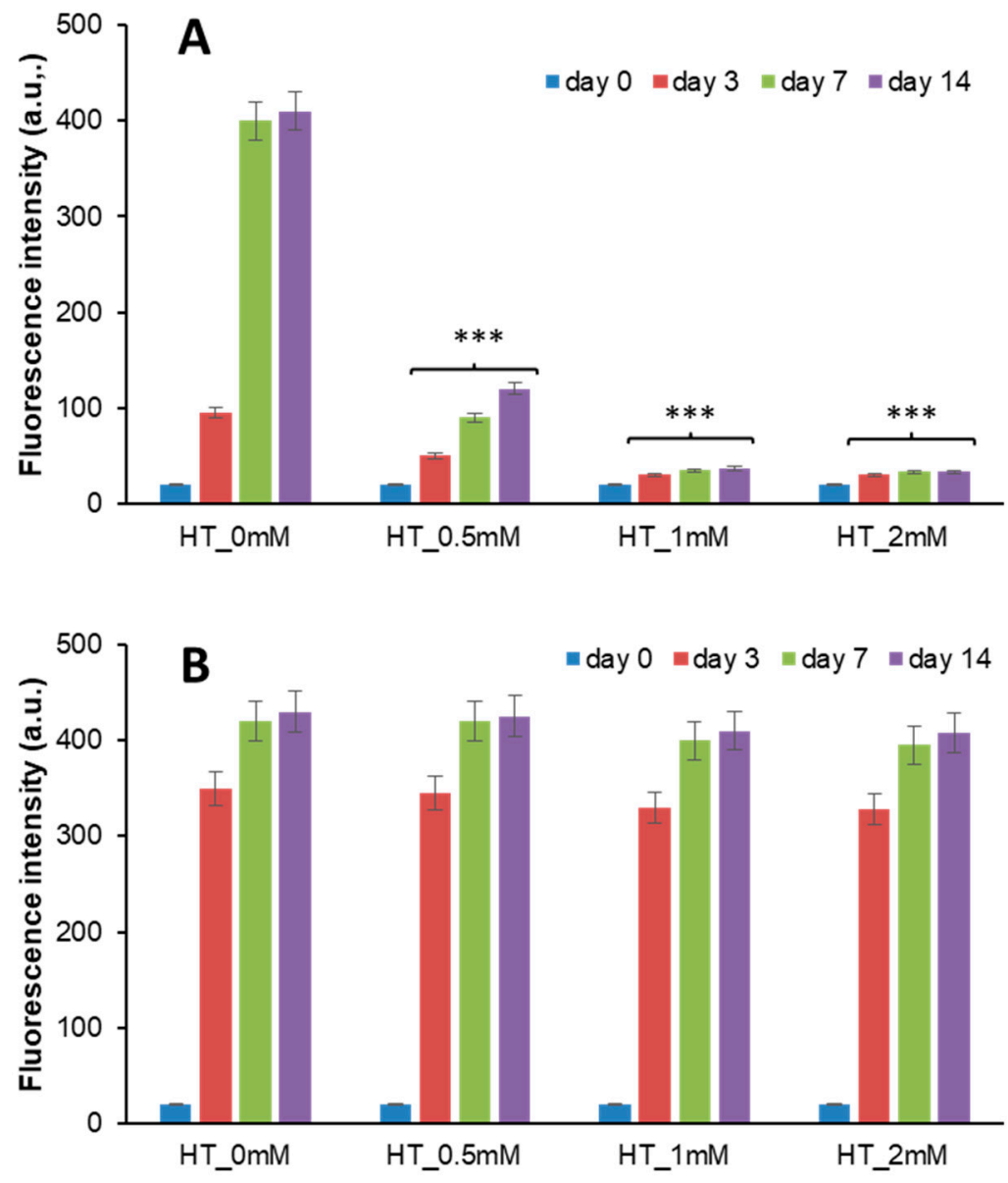

Figure 2. Effect of HT on insulin glycation kinetics. Insulin samples were incubated at $37^{\circ} \mathrm{C}$ with $0.5 \mathrm{M}$ D-ribose (A) and $1 \mathrm{mM}$ methylglyoxal (B) at different concentrations of HT (0-2 $\mathrm{mM})$ and AGE fluorescence ( $\lambda$ ex $320 \mathrm{~nm} / \lambda \mathrm{em} 410 \mathrm{~nm}$ ) was monitored at different time points. Other experimental details are described in the Methods section. ${ }^{* * *} p<0.001$ versus sample in the absence of HT (HT_0 mM).

As expected, the sample of insulin glycated by D-ribose without HT produced a marked emission intensity at $410 \mathrm{~nm}$ during the incubation time and the glycation reaction was completed in about 7 days (Figure 2A). Differently, in the presence of HT, a strong reduction of AGE formation was detected at all incubation times as suggested by a marked decrease of the fluorescence intensity. The inhibition of AGE formation was HT concentration dependent and $1 \mathrm{mM} \mathrm{HT}$ was enough to strongly restrain the process (Figure 2A). A different effect was observed for insulin sample glycated by MG (Figure 2B). Indeed, in this reaction the presence of HT did not perturb AGE fluorescence intensity, thus suggesting no effect on insulin-AGE formation.

Interestingly, these data indicate that HT differentially affects AGE formation in human insulin. In particular, while no effect is observed on insulin glycation by MG, a strong inhibitory effect is observed in the presence of D-ribose in a concentration-dependent manner.

Further confirmation of HT inhibition on insulin-AGE formation was obtained by cellular toxicity studies. Indeed, it is well established that AGE species promote cell toxicity and we have previously reported that insulin glycation by D-ribose produces AGE species able to strongly affect the cell viability in different cellular models [65,69]. To monitor the cytotoxicity of insulin-AGE formed in the presence of HT, we have monitored the cell viability in neurotypical cells by the MTT assay, which measures the cellular metabolic activity (Figure 3). To this aim, SHSY5Y cells were exposed for $24 \mathrm{~h}$ to insulin glycated for 7 days by D-ribose (InsRib) in the absence and in the presence of HT at different 
concentrations $(0 ; 0.5 ; 1 ; 2 \mathrm{mM})$. As expected, in the absence of HT, fully glycated species reduce cell viability by approximately $40 \%$ compared to untreated cells while samples glycated in the presence of HT showed no cell toxicity thus indicating the absence of AGE species in these samples. The same experiment was performed with insulin samples incubated in glycation condition for 14 days and, also in these samples, HT was inhibiting the formation of toxic AGE species (data not shown). These data further indicate that the presence of HT strongly inhibits the formation of AGE species by D-ribose in human insulin.

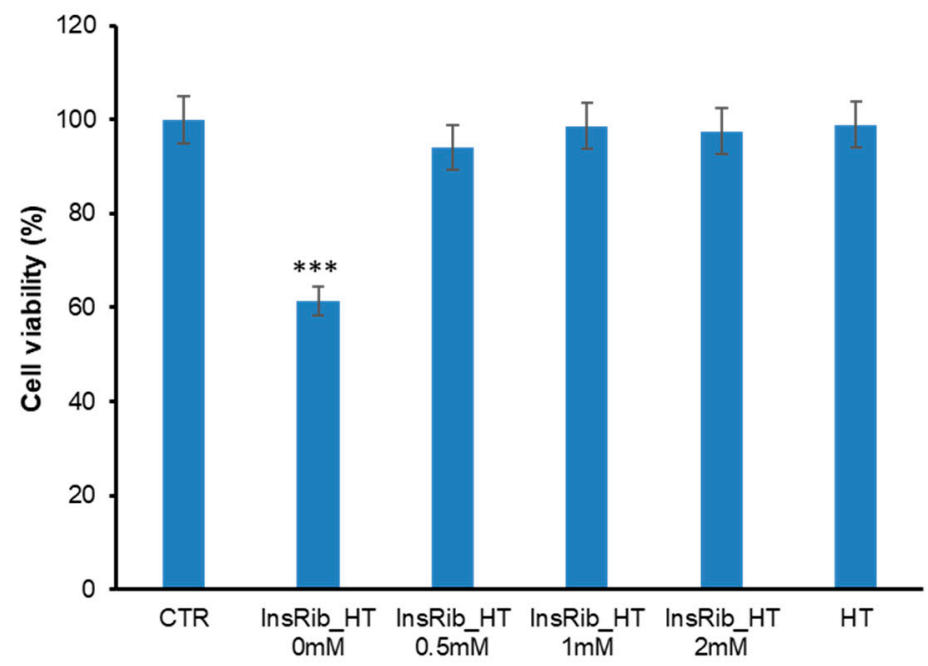

Figure 3. Cytotoxicity of insulin species glycated in the presence of HT. SHSY5Y cells were exposed for $24 \mathrm{~h}$ to insulin samples glycated with D-ribose in the presence of different concentrations of HT ( 0 , $0.5,1,2 \mathrm{mM}$ ) and the cell viability was evaluated by the MTT assay. Data are expressed as average percentage of MTT reduction \pm SD relative to control cells from triplicate wells from 5 separate experiments $(p<0.01)$. Other experimental details are described in the Methods section. ${ }^{* * *} p<0.001$ versus CTR.

\subsection{HT-Insulin Interaction in AGE Formation}

We have recently shown that HT specifically binds human insulin in a region close to tyrosine 26 residue in the B chain [70]. As the D-ribose glycation site (LysB29) is located in close proximity to Tyr26 in insulin structure, the binding of HT to human insulin could be responsible for the inhibition of glycation reaction as it could reduce the access of Dribose to this glycation site (Figure 4). To validate this hypothesis, the glycation reaction has been performed with D-ribose both in the presence and in the absence of HT and the tyrosine emission fluorescence has been monitored at the end of the process ( 7 days) (Figure 5). Insulin contains four tyrosyl residues as fluorescence emitters and its spectrum is characterized by the typical tyrosyl emission centered at $305 \mathrm{~nm}$. Figure 5 shows the emission fluorescence spectra of insulin glycated by D-ribose (InsRib) in the presence of HT at different molar ratios. 


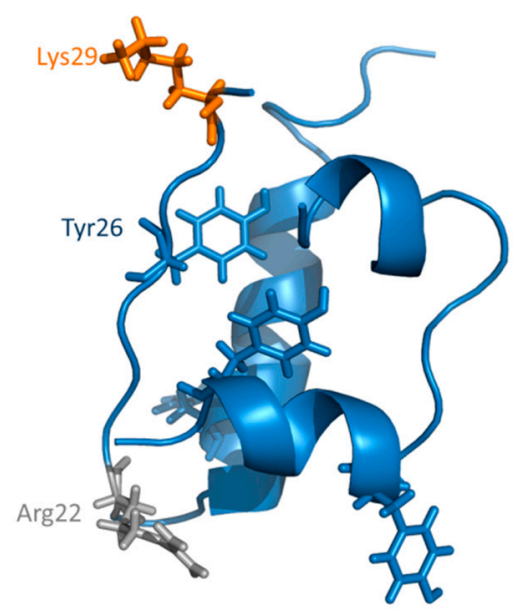

Figure 4. Glycation sites in human insulin. Structural representation of human insulin in its monomeric form (PDB 3AIY). In the tridimensional structure, D-ribose glycation site is represented in orange (Lys29), MG glycation site in gray (Arg22), and tyrosine residues are shown in blue.

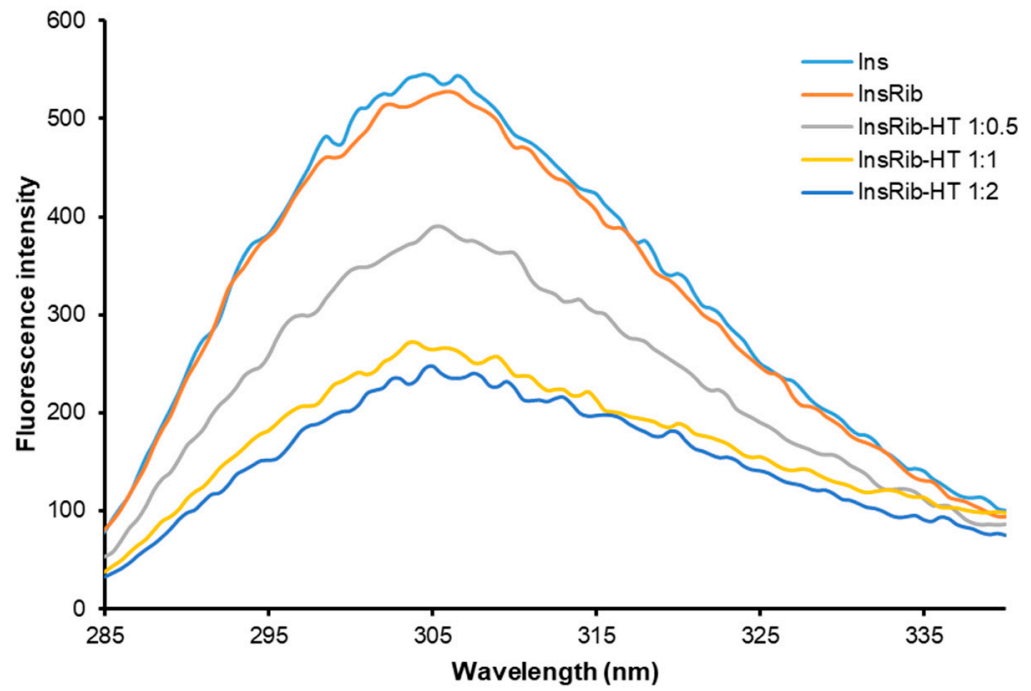

Figure 5. Glycated insulin-HT interaction monitored by intrinsic fluorescence spectroscopy. Tyrosine fluorescence emission has been detected in native insulin (Ins) and insulin glycated by D-ribose (InsRib) in the absence and in the presence of HT at different molar ratio (1:0, 1:0.5, 1:1, 1:2). Insulin working concentration was $10 \mu \mathrm{M}$. Other experimental details are described in the Methods section.

Emission spectra of native insulin in the absence of glycating agent and HT is also shown for comparison. In the absence of HT, the fluorescence emission of glycated insulin almost resembles that of the native protein, thus suggesting no variation in tyrosyl environment upon glycation. Interestingly, the fluorescence intensity regularly decreased in the samples glycated with D-ribose in the presence of increasing concentration of HT, thus suggesting that this molecule induces quenching of tyrosine emission. In addition, as only partial quenching of tyrosyl fluorescence is observed, we can hypothesize that the HT binding only affects few tyrosine residues in insulin structure. The same experiment was performed in the presence of MG as glycating agent but no effect of HT on tyrosyl emission was detected (data not shown), further supporting our hypothesis. The overall data suggest that HT binding might induce small conformational changes in the tyrosyl environment that could selectively reduce accessibility to the close D-ribose glycation site (LysB29). 


\subsection{HT Protective Effect in AGE-Induced Toxicity}

HT is a phenolic compound proposed to exert a wide range of biological effects, such as cardioprotective, anticancer, neuroprotective, antimicrobial, and anti-inflammatory [54-56]. As AGEs are known to induce cytotoxicity through the activation of inflammatory response and oxidative pathways, the ability of HT to protect by AGE toxicity in neurotypical cells exposed to fully glycated species was also investigated as this effect has been never tested before. In particular, the cell viability has been tested by the MTT assay in SHSY5Y cells co-incubated with ribosylated AGE-insulin (InsRib) and HT (1:1 and 1:2 molar ratio) for 24 and $48 \mathrm{~h}$ (Figure 6). As expected, glycated insulin induced a strong reduction of the cell viability $(40 \%$ at $24 \mathrm{~h}$ and $60 \%$ at $48 \mathrm{~h}$ ) while, in the presence of HT, no reduction was observed at any time point. Interestingly, HT was able to reverse the toxic effect of insulin-AGEs even at the lower concentration (1:1 molar ratio), thus suggesting a strong protective effect on AGE toxicity.

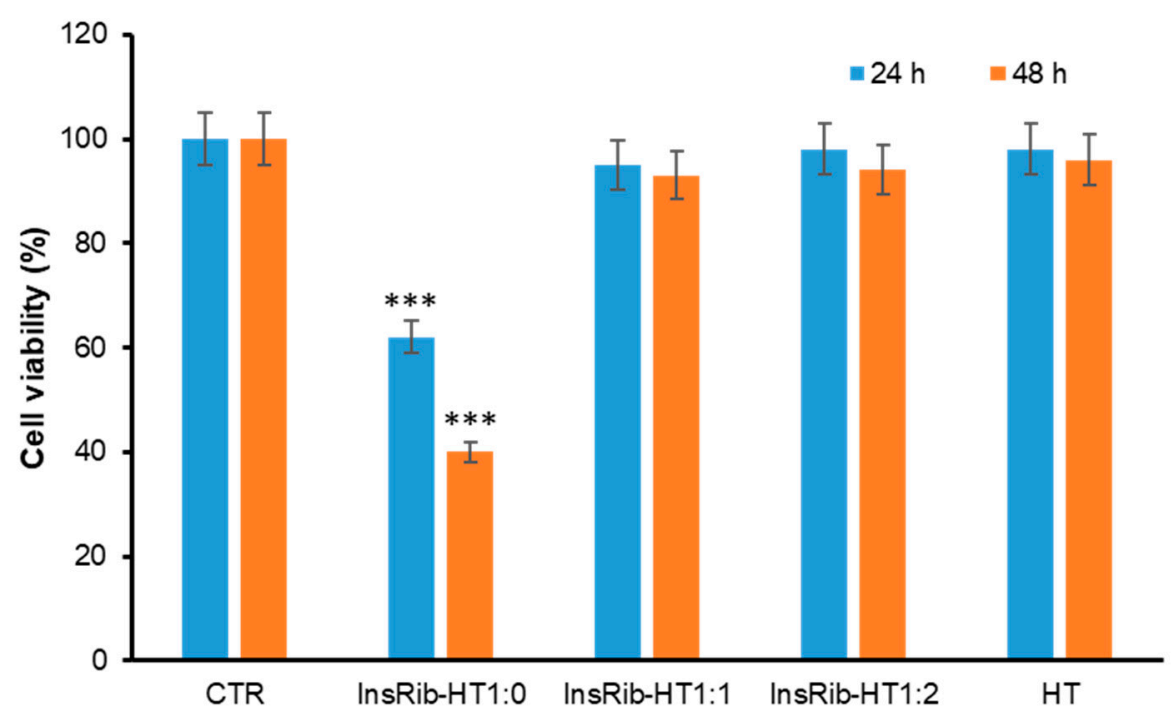

Figure 6. Effect of HT on insulin AGE toxicity. SHSY5Y cells were coincubated with glycated insulin and HT (1:0, 1:1, 1:2 molar ratio) and the cell viability was evaluated after 24 and $48 \mathrm{~h}$ by the MTT assay. CTR: cells treated with non-glycated insulin; HT: cells treated with HT at the higher working concentration; data are expressed as average percentage of MTT reduction \pm SD relative to control cells from triplicate wells from 5 separate experiments. Other experimental details are described in the Methods section. ${ }^{* * *} p<0.001$ versus CTR.

\subsection{HT Protective Effect on AGE-Induced Oxidative Stress and Inflammatory Pathways}

AGEs are generally responsible, via AGE-RAGE interaction, for an increase of oxidative stress and inflammatory response [29,71]. In order to identify the molecular basis of the cellular protection by which HT counteracts AGE toxicity, we have evaluated the effect of HT both on oxidative stress and inflammatory pathways induced by glycated insulin. At first, we have tested the ability of HT to reduce the AGE-induced ROS production. In particular, as insulin glycated by D-ribose (InsRib) is known to induce ROS production in SHSY5Y cells at $48 \mathrm{~h}$ incubation, we have measured the intracellular ROS levels in SHSY5Y cells co-incubated with insulin-AGEs and HT for $48 \mathrm{~h}$, by DCFH-DA fluorescence assay $[26,65,72]$ (Figure $7 \mathrm{~A}$ ). Interestingly, while InsRib promotes ROS production as indicated by the increase in the DCF fluorescence, in the sample co-incubated with HT a strong reduction (more than 85\%) of ROS levels was observed, thus suggesting that HT is able to counteract production of oxidative stress. Evaluation of oxidative stress was also performed through the evaluation of SOD2 expression, as mediator of ROS production (Figure 7B). The results show that cells treated with InsRib showed a reduced expression of SOD2 associated to an increase in oxidative stress. Interestingly, SOD2 level in cells 
cotreated with both InsRib and HT was similar to that of untreated cells, thus indicating that the presence of HT is able to counteract the AGE-dependent oxidative stress and protect cells from AGE-related toxicity.
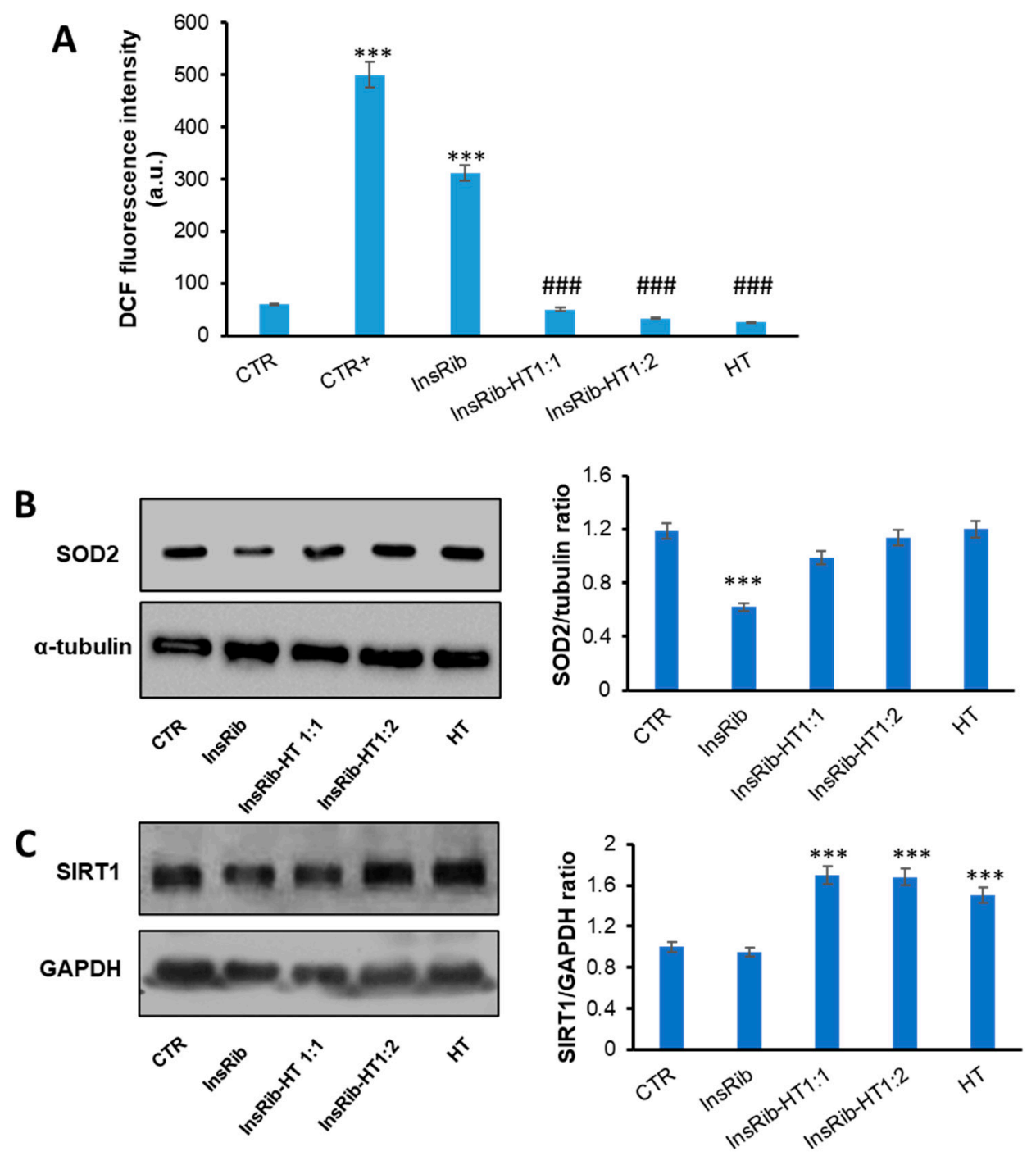

Figure 7. Role of HT in AGE-induced oxidative stress. SHSY5Y cells were co-incubated with glycated insulin (InsRib) and HT (1:0, 1:1, 1:2 molar ratio) and the effect of HT was evaluated in ROS production by DCFH-DA assay (A), SOD2 expression (B) and IRT1 expression (C) by western-blot analysis. CTR: cells treated with non-glycated insulin; HT: cells treated with the higher working concentration of HT; CTR+: cells treated with $1.0 \mathrm{mM} \mathrm{H}_{2} \mathrm{O}_{2}$. Data are expressed as average \pm S.D from five independent experiments carried out in triplicate. Other experimental details are described in the Methods section. ${ }^{* * *} p<0.001$ versus CTR, \#\#\# $p<0.001$ versus InsRib.

With the aim of further characterize the protective effect observed for HT in AGErelated oxidative damage, we have also evaluated the role of HT in molecular pathways involved in AGE oxidative stress. In this respect, SIRT1, a protein deacetylase, represents a very important key regulator in cellular protection as its activation markedly protects cells from oxidative stress injury and also hinders inflammatory pathways by inhibition of Nf-kB $[73,74]$. To probe the effect of HT on SIRT1 levels in AGE-induced toxicity, we have monitored SIRT1 expression in cells treated with InsRib in the presence and in the absence of $\mathrm{HT}$ at different concentrations. In particular, cells were exposed for $24 \mathrm{~h}$ to glycated insulin at different concentration of HT (1:0, 1:1, 1:2 molar ratio), and SIRT1 levels were evaluated by western-blot analysis (Figure 7B). 
Interestingly, while cells treated with glycated insulin showed no variation in SIRT1 expression compared to untreated cells, the ones cotreated with HT (both 1:1 and 1:2 molar ratio) showed an increased expression (80\%) of SIRT1. These results suggest that the protective effect observed for HT on AGE-induced oxidative stress is likely associated with the ability of HT to upregulate SIRT1 expression, thus contributing to boosting the cellular antioxidant pathways.

AGEs are also responsible, via AGE-RAGE interaction, for an increase of inflammatory response through the activation of $N F-\kappa B$, which in turn is responsible for an increased expression of proinflammatory cytokines and for the activation of the MAPK signalling pathway through the phosphorylation of extracellular signal-regulated kinases (ERK1/2) [27,28,71,75,76].

We have recently shown that glycated insulin promotes NF- $\mathrm{BB}$ and caspase $3 / 7$ activation in endothelial cells through the activation of the AGE-RAGE signaling pathway [65,69]. To better analyze the protective effect observed for HT in the AGE-related toxicity, we have evaluated both the NF-KB and ERK $1 / 2$ activation in cells exposed to InsRib in the absence and in the presence of HT. To this aim, SHSY5Y cells were co-incubated for $24 \mathrm{~h}$ with InsRib and HT (1:1 molar ratio) and activation of NF-kB as well as ERK 1/2 was evaluated by western-blot analysis (Figure 8). As expected, glycated insulin promotes the activation of NF- $\mathrm{kB}$ as indicated by a significant increase (8.6 fold) of phosho-NF- $\mathrm{kB}$ level compared to untreated cells. Differently, the cotreatment with HT reduces of almost 3-fold the NF- $\kappa B$ activation induced by AGE species, thus suggesting clear anti-inflammation activity (Figure 8A). Similarly, InsRib also promotes ERK $1 / 2$ activation as suggested by a 45 -fold increase of enzyme phosphorylation at $24 \mathrm{~h}$ incubation compared to untreated cells. Additionally, in this case, the cells co-incubated with glycated insulin and HT showed a reduced enzyme activation (3-fold reduction), thus suggesting that the protective effect observed for HT on AGE toxicity could be due to a modulation of NF-kB/ERK 1/2 pathway. In this respect, the modulation of SIRT1 by HT can both regulate inflammatory response through inhibition of NF- $\mathrm{KB}$ activation, and also boost the cellular response to oxidative stress $[73,74]$.
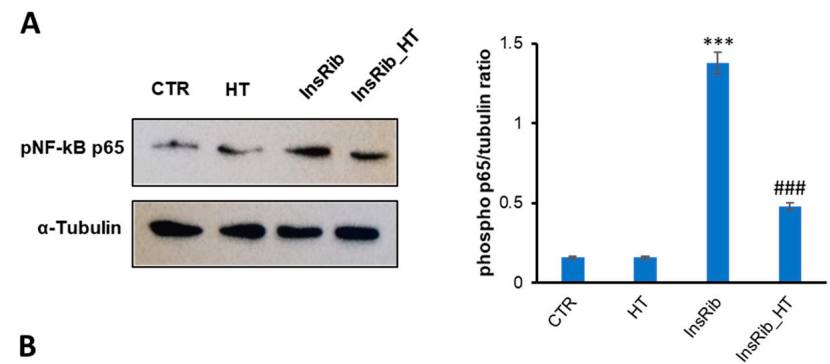

B

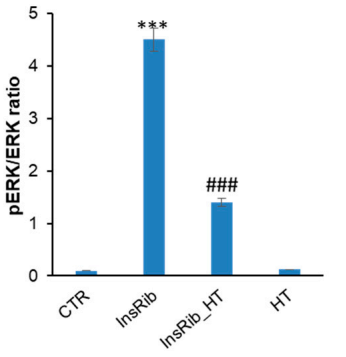

Figure 8. Effect of HT on NF-kB and Erk $1 / 2$ activation. Western-blot analysis of phosphorylated p65 NF-kB (A) and Erk 1/2 expression and phosphorylation (B) in SHSY5Y cells treated for $24 \mathrm{~h}$ with glycated insulin in the absence (InsRib) and in the presence of HT 1:1 molar ratio (InsRib_HT). CTR: untreated cells. HT: cells treated with only HT for $24 \mathrm{~h}$. Working concentrations were $40 \mu \mathrm{M}$ both for insulin and HT. Other experimental conditions are described in the Methods section. ${ }^{* * *} p<0.001$ versus CTR, \#\# $p<0.001$ versus InsRib. 


\section{Discussion}

Advanced glycation end-products (AGEs) are very reactive metabolites produced by the nonenzymatic glycation reaction between sugars and biological macromolecules such as protein, DNA, and lipids. AGEs accumulate both intracellularly and extracellularly and contribute both to the onset of multiple diseases and the subsequent disease complications. In fact, AGEs are considered pathological hallmarks in aging and various age-related chronic pathologies such as inflammation, neurodegenerative diseases, atherosclerosis, and vascular complications of diabetes mellitus [1-4]. In particular, it is well known that AGE accumulation and oxidative stress play a central role in the pathogenesis of neurodegenerative diseases [6,7]. The brain is particularly prone to oxidative damage due to poor antioxidant defenses [77]. AGE accumulation has been observed in brains affected by $\mathrm{AD}$ and $\mathrm{PD}$ as well as other neurodegenerative disorders [6]. Accumulation of AGE species is associated with increased protein dysfunction and aberrant activation of cellular signaling cascades. Formation of AGE cross-link accumulates over time, and it is stimulated by high glucose levels, as in diabetic patients. In addition, glycation of proteins has been reported to destabilize the native state and stimulate protein aggregation as well as amyloid deposition [21-26].

For this reason, much attention has been devoted to the identification of molecular targets able to prevent or limit the glycation reaction and the AGE-dependent cell damage. Several strategies have been developed to prevent the detrimental effect of AGEs, including the employment of natural or synthetic AGE inhibitors and compounds able to interfere with inflammation and oxidative stress. Although several synthetic compounds can efficiently inhibit AGE formation or break protein cross-links, they can be associated with severe side effects. Recently, great attention has been addressed to natural compounds such as polyphenols, well known for their antioxidants and anti-inflammatory properties [54-56]. In this respect, $\mathrm{HT}$ it has been reported to inhibit the glycation reaction by MG in bovine serum albumin and this effect seems to be ascribed to the ability of HT to specifically trap the MG $[78,79]$. Indeed, the inhibitory effect was observed only when the protein was glycated in the presence of similar concentrations of HT and MG (molar ratio MG:HT 1:1 and 2:1), while no effect was observed in the presence of MG excess (MG:HT ratio 10:1). In our study we have tested the ability of HT to affect the non-enzymatic glycation of human insulin in the presence of two different glycating agents, D-ribose and MG, used in a large excess to be independent from the potential trapping effect. Insulin is susceptible to in vivo glycation by D-ribose and reactive carbonyls, as MG, especially in diabetic conditions and AGE species are considered the main responsible for diabetes-related vascular complications $[17,62,64,80]$. Insulin can also be glycated in vitro and, in our conditions, the glycation reaction by D-ribose or MG is completed in few days [49,65]. Our results indicate that HT differentially affects insulin glycation in the presence of D-ribose and MG. Indeed, the presence of HT was hindering the AGE formation by D-ribose, but no effect was recorded in the presence of MG. In insulin glycation, D-ribose is known to react with $\mathrm{N}$-terminus and Lys29 of insulin B-chain while MG with a single site, i.e., Arg22 of insulin B chain [63]. The inhibitory effect observed for HT only in the presence of D-ribose might suggest that HT specifically interacts with insulin in a site close to the Lys29 thus hindering the glycation reaction. Interestingly, Lys 29 is very close to the Tyr26 and the tyrosine quenching induced by the presence of HT could further support this hypothesis. The region between Tyr26 and Lys29 is an unstructured region in human insulin that is likely to be stabilized by HT binding (Figure 4) as also suggested by a recent study in which we have shown that HT specifically binds human insulin in a region close to Lys29 in the B-chain [70]. Our study has also shown that the HT binding prevents the amyloid formation in human insulin by inducing stabilization of the region close to Lys29, responsible for amyloid aggregation [70]. In this respect, HT seems to possess a dual protective role as able to inhibit both toxic amyloid formation and protein glycation reaction.

Finally, as HT is known for its antioxidant and anti-inflammatory activity, we have tested the protective effect of HT on the toxicity induced by glycated species as this aspect 
was never explored before [54-56]. Interestingly, our results clearly show that HT exerts a protective effect on AGE-induced cytotoxicity even at micromolar concentrations. We have previously reported that glycated insulin strongly affects the cell viability, promoting a death pathway consisting in oxidative stress, apoptosis, and inflammatory response activation $[65,69]$. Our data show that, beside from its protective effect on cell mortality, HT is able to inhibit the AGE-induced ROS production when co-incubated with glycated insulin. The HT antioxidant effect on AGE-toxicity seems to be related to the ability of HT to specifically affect the SIRT1 level as the presence of HT upregulates SIRT1 expression thus keeping active the cellular antioxidant pathways. These observations are further supported by recent data indicating that HT is able to regulate SIRT1 expression in vascular adventitial fibroblasts also modulating the inflammatory response [81]. Moreover, our data show that HT significantly reduces the AGE-induced activation of NF- $\mathrm{kB}$ and ERK $1 / 2$ MAP kinase, thus suggesting inhibition of inflammatory pathways. In this respect, as SIRT1 markedly protects cells from oxidative stress injury and also hinders inflammatory pathways by inhibition of NF-kB [73,74], its upregulation by HT could be responsible for the cellular protection. Although further studies are needed to better elucidate this correlation, we could hypothesize that the HT protective effect in AGE toxicity is exerted through a SIRT1-dependent pathway [50,82-85] (Figure 9).

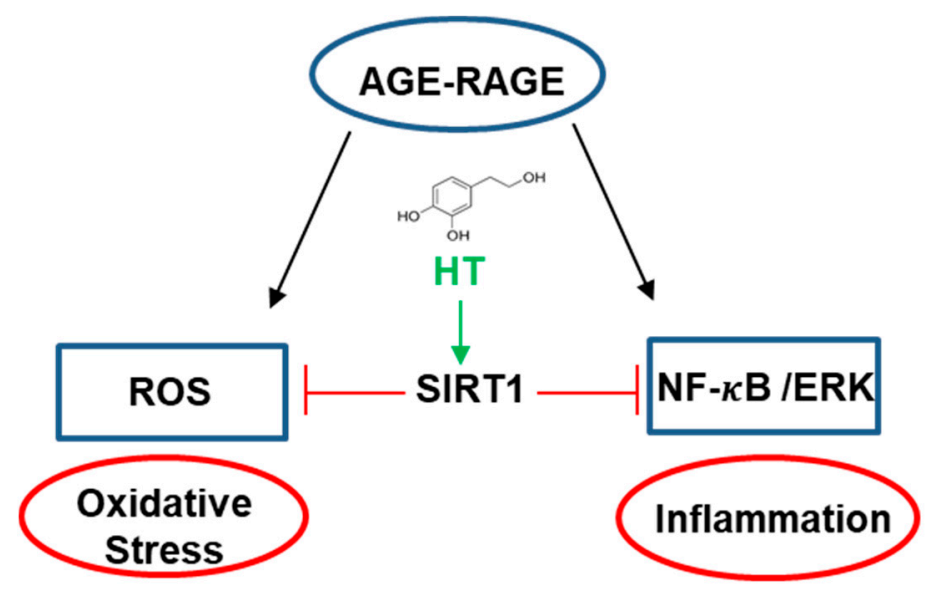

Figure 9. Working hypothesis on the protection effect of HT in AGE cytotoxicity. HT inhibits oxidative stress and inflammation response through the upregulation of SIRT1 expression.

\section{Conclusions}

The overall data identify HT as a potential inhibitor of glycation reaction as well as a promising molecule in protecting against the AGE-induced cellular dysfunctions, a key mechanism underlying the development and progression of neurodegenerative disorders. These findings indicate that the beneficial effects of olive oil polyphenols, including HT, observed in neurodegenerative diseases, may arise from multifunctional activities, thus suggesting a possible use of HT as nutraceutic in the prevention and/or treatment of AGE-related diseases, especially in consideration of its good safety profile and the ability to cross the blood brain barrier [85].

Author Contributions: Conceptualization, C.I. and I.S.; validation, M.B., M.L., P.R. and M.S.; formal analysis, M.B., M.L., P.R. and M.S.; writing-original draft preparation, C.I.; writing-review and editing, C.I. and I.S.; funding acquisition, C.I. All authors have read and agreed to the published version of the manuscript.

Funding: This work was supported by grants from MIUR (Programma Giovani Ricercatori Rita Levi Montalcini).

Institutional Review Board Statement: Not applicable.

Informed Consent Statement: Not applicable. 
Data Availability Statement: Data is contained within the article.

Conflicts of Interest: The authors declare no conflict of interest. The funders had no role in the design of the study; in the collection, analyses, or interpretation of data; in the writing of the manuscript, or in the decision to publish the results.

\section{References}

1. Nigro, C.; Leone, A.; Fiory, F.; Prevenzano, I.; Nicolò, A.; Mirra, P.; Beguinot, F.; Miele, C. Dicarbonyl Stress at the Crossroads of Healthy and Unhealthy Aging. Cells 2019, 8, 749. [CrossRef]

2. Schalkwijk, C.G.; Stehouwer, C.D.A. Methylglyoxal, a Highly Reactive Dicarbonyl Compound, in Diabetes, Its Vascular Complications, and Other Age-Related Diseases. Physiol. Rev. 2020, 100, 407-461. [CrossRef]

3. Hashimoto, K.; Kunikata, H.; Yasuda, M.; Ito, A.; Aizawa, N.; Sawada, S.; Kondo, K.; Satake, C.; Takano, Y.; Nishiguchi, K.M.; et al. The relationship between advanced glycation end products and ocular circulation in type 2 diabetes. J. Diabetes Compl. 2016, 30, 1371-1377. [CrossRef] [PubMed]

4. Grillo, M.A.; Colombatto, S. Advanced glycation end-products (AGEs): Involvement in aging and in neurodegenerative diseases. Amino Acids 2007, 35, 29-36. [CrossRef] [PubMed]

5. Ahmad, S.; Farhan, M. Impact of Non-Enzymatic Glycation in Neurodegenerative Diseases: Role of Natural Products in Prevention. Adv. Neurobiol. 2016, 12, 125-151. [CrossRef] [PubMed]

6. Salahuddin, P.; Rabbani, G.; Khan, R.H. The role of advanced glycation end products in various types of neurodegenerative disease: A therapeutic approach. Cell. Mol. Biol. Lett. 2014, 19, 407-437. [CrossRef]

7. Hrelia, P.; Sita, G.; Ziche, M.; Ristori, E.; Marino, A.; Cordaro, M.; Molteni, R.; Spero, V.; Malaguti, M.; Morroni, F.; et al. Common Protective Strategies in Neurodegenerative Disease: Focusing on Risk Factors to Target the Cellular Redox System. Oxidative Med. Cell. Longev. 2020, 2020, 8363245. [CrossRef]

8. Takeuchi, M. Possible Involvement of Advanced Glycation End-Products (AGEs) in the Pathogenesis of Alzheimers Disease. Curr. Pharm. Des. 2008, 14, 973-978. [CrossRef] [PubMed]

9. Mittal, K.; Katare, D.P. Shared links between type 2 diabetes mellitus and Alzheimer's disease: A review. Diabetes Metab. Syndr. Clin. Res. Rev. 2016, 10, S144-S149. [CrossRef] [PubMed]

10. Batkulwar, K.; Godbole, R.K.; Banarjee, R.M.; Kassaar, O.M.; Williams, R.J.; Kulkarni, M.J. Advanced Glycation End Products Modulate Amyloidogenic APP Processing and Tau Phosphorylation: A Mechanistic Link between Glycation and the Development of Alzheimer's Disease. ACS Chem. Neurosci. 2018, 9, 988-1000. [CrossRef]

11. Jash, K.; Gondaliya, P.; Kirave, P.; Kulkarni, B.; Sunkaria, A.; Kalia, K. Cognitive dysfunction: A growing link between diabetes and Alzheimer's disease. Drug Dev. Res. 2020, 81, 144-164. [CrossRef]

12. Chou, P.-S.; Wu, M.-N.; Yang, C.-C.; Shen, C.-T.; Yang, Y.-H. Effect of Advanced Glycation End Products on the Progression of Alzheimer's Disease. J. Alzheimers Dis. 2019, 72, 191-197. [CrossRef] [PubMed]

13. Kong, Y.; Wang, F.; Wang, J.; Liu, C.; Zhou, Y.; Xu, Z.; Zhang, C.; Sun, B.; Guan, Y. Pathological Mechanisms Linking Diabetes Mellitus and Alzheimer's Disease: The Receptor for Advanced Glycation End Products (RAGE). Front. Aging Neurosci. 2020, 12, 217. [CrossRef] [PubMed]

14. Singh, R.; Barden, A.; Mori, T.; Beilin, L. Advanced glycation end-products: A review. Diabetologia 2001, 44, 129-146. [CrossRef] [PubMed]

15. Gugliucci, A. Formation of Fructose-Mediated Advanced Glycation End Products and Their Roles in Metabolic and Inflammatory Diseases. Adv. Nutr. 2017, 8, 54-62. [CrossRef]

16. Nass, N.; Bartling, B.; Navarrete Santos, A.; Scheubel, R.J.; Börgermann, J.; Silber, R.E.; Simm, A. Advanced glycation end products, diabetes and ageing. Z. Gerontol. Geriatr. 2007, 40, 349-356. [CrossRef] [PubMed]

17. Singh, V.P.; Bali, A.; Singh, N.; Jaggi, A.S. Advanced Glycation End Products and Diabetic Complications. Korean J. Physiol. Pharmacol. 2014, 18, 1-14. [CrossRef] [PubMed]

18. Chaudhuri, J.; Bains, Y.; Guha, S.; Kahn, A.; Hall, D.; Bose, N.; Gugliucci, A.; Kapahi, P. The Role of Advanced Glycation End Products in Aging and Metabolic Diseases: Bridging Association and Causality. Cell Metab. 2018, 28, 337-352. [CrossRef]

19. Perkins, R.K.; Miranda, E.R.; Karstoft, K.; Beisswenger, P.J.; Solomon, T.P.J.; Haus, J.M. Experimental Hyperglycemia Alters Circulating Concentrations and Renal Clearance of Oxidative and Advanced Glycation End Products in Healthy Obese Humans. Nutrients 2019, 11, 532. [CrossRef]

20. Wautier, J.-L.; Schmidt, A.M. Protein Glycation: A firm link to endothelial cell dysfunction. Circ. Res. 2004, 95, 233-238. [CrossRef]

21. Iannuzzi, C.; Irace, G.; Sirangelo, I. Differential effects of glycation on protein aggregation and amyloid formation. Front. Mol. Biosci. 2014, 1, 9. [CrossRef]

22. Vitek, M.P.; Bhattacharya, K.; Glendening, J.M.; Stopa, E.; Vlassara, H.; Bucala, R.; Manogue, K.; Cerami, A. Advanced glycation end products contribute to amyloidosis in Alzheimer disease. Proc. Natl. Acad. Sci. USA 1994, 91, 4766-4770. [CrossRef]

23. Münch, G.; Mayer, S.; Michaelis, J.; Hipkiss, A.R.; Riederer, P.; Müller, R.; Neumann, A.; Schinzel, R.; Cunningham, A.M. Influence of advanced glycation end-products and AGE-inhibitors on nucleation-dependent polymerization of $\beta$-amyloid peptide. Biochim. Biophys. Acta BBA Mol. Basis Dis. 1997, 1360, 17-29. [CrossRef] 
24. Kikuchi, S.; Ogata, A.; Shinpo, K.; Moriwaka, F.; Fujii, J.; Taniguchi, N.; Tashiro, K. Detection of an Amadori product, 1-hexitollysine, in the anterior horn of the amyotrophic lateral sclerosis and spinobulbar muscular atrophy spinal cord: Evidence for early involvement of glycation in motoneuron diseases. Acta Neuropathol. 2000, 99, 63-66. [CrossRef] [PubMed]

25. Iannuzzi, C.; Carafa, V.; Altucci, L.; Irace, G.; Borriello, M.; Vinciguerra, R.; Sirangelo, I. Glycation of Wild-Type Apomyoglobin Induces Formation of Highly Cytotoxic Oligomeric Species. J. Cell. Physiol. 2015, 230, 2807-2820. [CrossRef] [PubMed]

26. Sirangelo, I.; Vella, F.M.; Irace, G.; Manco, G.; Iannuzzi, C. Glycation in Demetalated Superoxide Dismutase 1 Prevents Amyloid Aggregation and Produces Cytotoxic Ages Adducts. Front. Mol. Biosci. 2016, 3, 55. [CrossRef] [PubMed]

27. Riehl, A.; Németh, J.; Angel, P.; Hess, J. The receptor RAGE: Bridging inflammation and cancer. Cell Commun. Signal. 2009, 7, 12. [CrossRef] [PubMed]

28. Soman, S.; Raju, R.; Sandhya, V.K.; Advani, J.; Khan, A.A.; Harsha, H.C.; Prasad, T.S.K.; Sudhakaran, P.R.; Pandey, A.; Adishesha, P.K. A multicellular signal transduction network of AGE/RAGE signaling. J. Cell Commun. Signal. 2012, 7, 19-23. [CrossRef] [PubMed]

29. Ott, C.; Jacobs, K.; Haucke, E.; Navarrete Santos, A.; Grune, T.; Simm, A. Role of advanced glycation end products in cellular signaling. Redox Biol. 2014, 2, 411-429. [CrossRef]

30. Hudson, B.I.; Lippman, M.E. Targeting RAGE Signaling in Inflammatory Disease. Annu. Rev. Med. 2018, 69, 349-364. [CrossRef]

31. Prasad, K.; Tiwari, S. Therapeutic Interventions for Advanced Glycation-End Products and its Receptor- Mediated Cardiovascular Disease. Curr. Pharm. Des. 2017, 23, 937-943. [CrossRef] [PubMed]

32. Fishman, S.L.; Sonmez, H.; Basman, C.; Singh, V.; Poretsky, L. The role of advanced glycation end-products in the development of coronary artery disease in patients with and without diabetes mellitus: A review. Mol. Med. 2018, 24, 1-12. [CrossRef] [PubMed]

33. Knani, I.; Bouzidi, H.; Zrour, S.; Bergaoui, N.; Hammami, M.; Kerkeni, M. Increased serum concentrations of Necarboxymethyllysine are related to the presence and the severity of rheumatoid arthritis. Ann. Clin. Biochem. Int. J. Lab. Med. 2017, 55, 430-436. [CrossRef]

34. Prasad, K. AGE-RAGE Stress in the Pathophysiology of Atrial Fibrillation and Its Treatment. Int. J. Angiol. 2020, 29, 72-80. [CrossRef] [PubMed]

35. Waghela, B.N.; Vaidya, F.U.; Ranjan, K.; Chhipa, A.S.; Tiwari, B.S.; Pathak, C. AGE-RAGE synergy influences programmed cell death signaling to promote cancer. Mol. Cell. Biochem. 2021, 476, 585-598. [CrossRef]

36. Juranek, J.; Ray, R.; Banach, M.; Rai, V. Receptor for advanced glycation end-products in neurodegenerative diseases. Rev. Neurosci. 2015, 26, 691-698. [CrossRef]

37. Abate, G.; Marziano, M.; Rungratanawanich, W.; Memo, M.; Uberti, D. Nutrition and AGE-ing: Focusing on Alzheimer's Disease. Oxidative Med. Cell. Longev. 2017, 2017, 1-10. [CrossRef] [PubMed]

38. Buelna-Chontal, M.; Zazueta, C. Redox activation of Nrf2 \& NF-kB: A double end sword? Cell. Signal. 2013, $25,2548-2557$. [CrossRef]

39. Zhang, J.; Wang, X.; Vikash, V.; Ye, Q.; Wu, D.; Liu, Y.; Dong, W. ROS and ROS-Mediated Cellular Signaling. Oxidative Med. Cell. Longev. 2016, 2016, 4350965. [CrossRef]

40. Bierhaus, A.; Humpert, P.M.; Morcos, M.; Wendt, T.; Chavakis, T.; Arnold, B.; Stern, D.M.; Nawroth, P.P. Understanding RAGE, the receptor for advanced glycation end products. J. Mol. Med. 2005, 83, 876-886. [CrossRef]

41. Chuah, Y.K.; Basir, R.; Talib, H.; Tie, T.H.; Nordin, N. Receptor for Advanced Glycation End Products and Its Involvement in Inflammatory Diseases. Int. J. Inflamm. 2013, 2013, 403460. [CrossRef] [PubMed]

42. Wautier, M.-P.; Chappey, O.; Corda, S.; Stern, D.M.; Schmidt, A.M.; Wautier, J.-L. Activation of NADPH oxidase by AGE links oxidant stress to altered gene expression via RAGE. Am. J. Physiol. Metab. 2001, 280, E685-E694. [CrossRef]

43. Xie, J.; Méndez, J.D.; Méndez-Valenzuela, V.; Hernandez, M.M.A. Cellular signalling of the receptor for advanced glycation end products (RAGE). Cell. Signal. 2013, 25, 2185-2197. [CrossRef] [PubMed]

44. Chen, X.; Wu, W.; Zhou, Q.; Jie, J.; Chen, X.; Wang, F.; Gong, X. Retracted: Advanced glycation end-products induce oxidative stress through the Sirt1/Nrf2 axis by interacting with the receptor of AGEs under diabetic conditions. J. Cell. Biochem. 2019, 120, 2159-2170. [CrossRef]

45. Rowan, S.; Bejarano, E.; Taylor, A. Mechanistic targeting of advanced glycation end-products in age-related diseases. Biochim. Biophys. Acta BBA Mol. Basis Dis. 2018, 1864, 3631-3643. [CrossRef]

46. Shen, C.-Y.; Lu, C.-H.; Wu, C.-H.; Li, K.-J.; Kuo, Y.-M.; Hsieh, S.-C.; Yu, C.-L. The Development of Maillard Reaction, and Advanced Glycation End Product (AGE)-Receptor for AGE (RAGE) Signaling Inhibitors as Novel Therapeutic Strategies for Patients with AGE-Related Diseases. Molecules 2020, 25, 5591. [CrossRef]

47. Bhullar, K.S.; Rupasinghe, H.P.V. Polyphenols: Multipotent Therapeutic Agents in Neurodegenerative Diseases. Oxidative Med. Cell. Longev. 2013, 2013, 891748. [CrossRef]

48. Sadowska-Bartosz, I.; Bartosz, G. Prevention of Protein Glycation by Natural Compounds. Molecules 2015, 20, 3309-3334. [CrossRef]

49. Iannuzzi, C.; Borriello, M.; Irace, G.; Cammarota, M.; Di Maro, A.; Sirangelo, I. Vanillin Affects Amyloid Aggregation and Non-Enzymatic Glycation in Human Insulin. Sci. Rep. 2017, 7, 15086. [CrossRef]

50. Yeh, W.-J.; Hsia, S.-M.; Lee, W.-H.; Wu, C.-H. Polyphenols with antiglycation activity and mechanisms of action: A review of recent findings. J. Food Drug Anal. 2017, 25, 84-92. [CrossRef] [PubMed] 
51. González, I.; Morales, M.A.; Rojas, A. Polyphenols and AGEs/RAGE axis. Trends and challenges. Food Res. Int. $2020,129,108843$. [CrossRef]

52. Peng, X.; Ma, J.; Chen, F.; Wang, M. Naturally occurring inhibitors against the formation of advanced glycation end-products. Food Funct. 2011, 2, 289-301. [CrossRef] [PubMed]

53. Hu, T.; He, X.-W.; Jiang, J.-G.; Xu, X.-L. Hydroxytyrosol and Its Potential Therapeutic Effects. J. Agric. Food Chem. 2014, 62, 1449-1455. [CrossRef]

54. Rodríguez-Morató, J.; Xicota, L.; Fitó, M.; Farré, M.; Dierssen, M.; De La Torre, R. Potential Role of Olive Oil Phenolic Compounds in the Prevention of Neurodegenerative Diseases. Molecules 2015, 20, 4655-4680. [CrossRef] [PubMed]

55. Robles-Almazan, M.; Pulido-Moran, M.; Moreno-Fernandez, J.; Ramirez-Tortosa, C.; Rodriguez-Garcia, C.; Quiles, J.L.; RamirezTortosa, M. Hydroxytyrosol: Bioavailability, toxicity, and clinical applications. Food Res. Int. 2018, 105, 654-667. [CrossRef]

56. Karković Marković, A.; Torić, J.; Barbarić, M.; Jakobušić Brala, C. Hydroxytyrosol, Tyrosol and Derivatives and Their Potential Effects on Human Health. Molecules 2019, 24, 2001. [CrossRef]

57. Bertelli, M.; Kiani, A.K.; Paolacci, S.; Manara, E.; Kurti, D.; Dhuli, K.; Bushati, V.; Miertus, J.; Pangallo, D.; Baglivo, M.; et al. Hydroxytyrosol: A natural compound with promising pharmacological activities. J. Biotechnol. 2020, 309, 29-33. [CrossRef]

58. Navarro, M.; Morales, F.J. Effect of hydroxytyrosol and olive leaf extract on 1,2-dicarbonyl compounds, hydroxymethylfurfural and advanced glycation endproducts in a biscuit model. Food Chem. 2017, 217, 602-609. [CrossRef] [PubMed]

59. Oya, T.; Hattori, N.; Mizuno, Y.; Miyata, S.; Maeda, S.; Osawa, T.; Uchida, K. Methylglyoxal Modification of Protein. Chemical and immunochemical characterization of methylglyoxal-arginine adducts. J. Biol. Chem. 1999, 274, 18492-18502. [CrossRef] [PubMed]

60. Lindsay, J.R.; McKillop, A.M.; Mooney, M.H.; O'Harte, F.P.M.; Bell, P.M.; Flatt, P. Demonstration of increased concentrations of circulating glycated insulin in human Type 2 diabetes using a novel and specific radioimmunoassay. Diabetologia 2003, 46, 475-478. [CrossRef]

61. Hunter, S.J.; Boyd, A.C.; O’Harte, F.; McKillop, A.M.; Wiggam, M.I.; Mooney, M.H.; McCluskey, J.T.; Lindsay, J.R.; Ennis, C.N.; Gamble, R.; et al. Demonstration of Glycated Insulin in Human Diabetic Plasma and Decreased Biological Activity Assessed by Euglycemic-Hyperinsulinemic Clamp Technique in Humans. Diabetes 2003, 52, 492-498. [CrossRef] [PubMed]

62. Jia, X.; Olson, D.J.H.; Ross, A.R.S.; Wu, L. Structural and functional changes in human insulin induced by methylglyoxal. FASEB J. 2006, 20, 1555-1557. [CrossRef] [PubMed]

63. Oliveira, L.M.; Lages, A.; Gomes, R.A.; Neves, H.; Família, C.; Coelho, A.V.; Quintas, A. Insulin glycation by methylglyoxal results in native-like aggregation and inhibition of fibril formation. BMC Biochem. 2011, 12, 41. [CrossRef] [PubMed]

64. Schalkwijk, C.G. Vascular AGE-ing by methylglyoxal: The past, the present and the future. Diabetologia 2015, 58, 1715-1719. [CrossRef] [PubMed]

65. Iannuzzi, C.; Borriello, M.; Carafa, V.; Altucci, L.; Vitiello, M.; Balestrieri, M.L.; Ricci, G.; Irace, G.; Sirangelo, I. D-ribose-glycation of insulin prevents amyloid aggregation and produces cytotoxic adducts. Biochim. Biophys. Acta BBA Mol. Basis Dis. 2016, 1862, 93-104. [CrossRef] [PubMed]

66. Chung, L.H.C.; Birch, D.J.S.; Vyshemirsky, V.; Ryadnov, M.G.; Rolinski, O.J. Tracking Insulin Glycation in Real Time by TimeResolved Emission Spectroscopy. J. Phys. Chem. B 2019, 123, 7812-7817. [CrossRef]

67. Iannuzzi, C.; Borriello, M.; Portaccio, M.; Irace, G.; Sirangelo, I. Insights into Insulin Fibril Assembly at Physiological and Acidic $\mathrm{pH}$ and Related Amyloid Intrinsic Fluorescence. Int. J. Mol. Sci. 2017, 18, 2551. [CrossRef]

68. Matiacevich, S.B.; Buera, M.P. A critical evaluation of fluorescence as a potential marker for the Maillard reaction. Food Chem. 2005, 95, 423-430. [CrossRef]

69. Borriello, M.; Iannuzzi, C.; Sirangelo, I. Pinocembrin Protects from AGE-Induced Cytotoxicity and Inhibits Non-Enzymatic Glycation in Human Insulin. Cells 2019, 8, 385. [CrossRef] [PubMed]

70. Sirangelo, I.; Borriello, M.; Vilasi, S.; Iannuzzi, C. Hydroxytyrosol Inhibits Protein Oligomerization and Amyloid Aggregation in Human Insulin. Int. J. Mol. Sci. 2020, 21, 4636. [CrossRef] [PubMed]

71. Tobon-Velasco, J.C.; Cuevas, E.; Torres-Ramos, M.A. Receptor for AGEs (RAGE) as Mediator of NF-kB Pathway Activation in Neuroinflammation and Oxidative Stress. CNS Neurol. Disord. Drug Targets 2014, 13, 1615-1626. [CrossRef]

72. Iannuzzi, C.; Borriello, M.; D'Agostino, A.; Cimini, D.; Schiraldi, C.; Sirangelo, I. Protective effect of extractive and biotechnological chondroitin in insulin amyloid and advanced glycation end product-induced toxicity. J. Cell. Physiol. 2019, 234, 3814-3828. [CrossRef]

73. Cai, W.; Ramdas, M.; Zhu, L.; Chen, X.; Striker, G.E.; Vlassara, H. Oral advanced glycation endproducts (AGEs) promote insulin resistance and diabetes by depleting the antioxidant defenses AGE receptor-1 and sirtuin 1. Proc. Natl. Acad. Sci. USA 2012, 109, 15888-15893. [CrossRef]

74. De Gregorio, E.; Colell, A.; Morales, A.; Marí, M. Relevance of SIRT1-NF-кB Axis as Therapeutic Target to Ameliorate Inflammation in Liver Disease. Int. J. Mol. Sci. 2020, 21, 3858. [CrossRef]

75. Chhipa, A.S.; Borse, S.P.; Baksi, R.; Lalotra, S.; Nivsarkar, M. Targeting receptors of advanced glycation end products (RAGE): Preventing diabetes induced cancer and diabetic complications. Pathol. Res. Pract. 2019, 215, 152643. [CrossRef] [PubMed]

76. Perrone, A.; Giovino, A.; Benny, J.; Martinelli, F. Advanced Glycation End Products (AGEs): Biochemistry, Signaling, Analytical Methods, and Epigenetic Effects. Oxidative Med. Cell. Longev. 2020, 2020, 1-18. [CrossRef] [PubMed]

77. Schulz, J.B.; Lindenau, J.; Seyfried, J.; Dichgans, J. Glutathione, oxidative stress and neurodegeneration. Eur. J. Biochem. 2000, 267, 4904-4911. [CrossRef] [PubMed] 
78. Navarro, M.; Morales, F.J. Mechanism of reactive carbonyl species trapping by hydroxytyrosol under simulated physiological conditions. Food Chem. 2015, 175, 92-99. [CrossRef]

79. Navarro, M.; Morales, F.J. In vitro investigation on the antiglycative and carbonyl trapping activities of hydroxytyrosol. Eur. Food Res. Technol. 2016, 242, 1101-1110. [CrossRef]

80. Rhee, S.Y.; Kim, Y.S. The Role of Advanced Glycation End Products in Diabetic Vascular Complications. Diabetes Metab. J. 2018, 42, 188-195. [CrossRef]

81. Wang, W.; Jing, T.; Yang, X.; He, Y.; Wang, B.; Xiao, Y.; Shang, C.; Zhang, J.; Lin, R. Hydroxytyrosol regulates the autophagy of vascular adventitial fibroblasts through the SIRT1-mediated signaling pathway. Can. J. Physiol. Pharmacol. 2018, 96, 88-96. [CrossRef] [PubMed]

82. Yang, X.; Jing, T.; Li, Y.; He, Y.; Zhang, W.; Wang, B.; Xiao, Y.; Wang, W.; Zhang, J.; Wei, J.; et al. Hydroxytyrosol Attenuates LPS-Induced Acute Lung Injury in Mice by Regulating Autophagy and Sirtuin Expression. Curr. Mol. Med. 2017, 17, 149-159. [CrossRef] [PubMed]

83. Huang, X.; Shi, Y.; Chen, H.; Le, R.; Gong, X.; Xu, K.; Zhu, Q.; Shen, F.; Chen, Z.; Gu, X.; et al. Isoliquiritigenin prevents hyperglycemia-induced renal injuries by inhibiting inflammation and oxidative stress via SIRT1-dependent mechanism. Cell Death Dis. 2020, 11, 1040. [CrossRef]

84. Huang, K.; Chen, C.; Hao, J.; Huang, J.; Wang, S.; Liu, P.; Huang, H. Polydatin promotes Nrf2-ARE anti-oxidative pathway through activating Sirt1 to resist AGEs-induced upregulation of fibronetin and transforming growth factor- $\beta 1$ in rat glomerular messangial cells. Mol. Cell. Endocrinol. 2015, 399, 178-189. [CrossRef] [PubMed]

85. Cabrerizo, S.; De La Cruz, J.P.; López-Villodres, J.A.; Muñoz-Marín, J.; Guerrero, A.; Reyes, J.J.; Labajos, M.T.; Gonzalez-Correa, J.A. Role of the inhibition of oxidative stress and inflammatory mediators in the neuroprotective effects of hydroxytyrosol in rat brain slices subjected to hypoxia reoxygenation. J. Nutr. Biochem. 2013, 24, 2152-2157. [CrossRef] [PubMed] 